\title{
A framework of numerical simulation on moraine-dammed glacial lake outburst floods
}

\author{
ZHANG Xiujuan ${ }^{1,2^{*}}$, LIU Shiyin ${ }^{1}$ \\ ${ }^{1}$ State Key Laboratory of Cryospheric Sciences, Cold and Arid Regions Environmental and Engineering Research Institute, \\ Chinese Academy of Sciences, Lanzhou 730000, China; \\ ${ }^{2}$ University of Chinese Academy of Sciences, Beijing 100049, China
}

\begin{abstract}
Glacial outburst floods (GLOFs) in alpine regions tend to be relatively complicated, multi-stage catastrophes, capable of causing significant geomorphologic changes in channel surroundings and posing severe threats to infrastructure and the safety and livelihoods of human communities. GLOF disasters have been observed and potential hazards can be foreseen due to the newly formed glacial lakes or the expansion of existing ones in the Poiqu River Basin in Tibet, China. Here we presented a synthesis of GLOF-related studies including triggering mechanism(s), dam breach modeling, and flood routing simulation that have been employed to reconstruct or forecast GLOF hydrographs. We provided a framework for probability-based GLOFs simulation and hazard mapping in the Poiqu River Basin according to available knowledge. We also discussed the uncertainties and challenges in the model chains, which may form the basis for further research.
\end{abstract}

Keyw ords: moraine-dammed glacial lakes; glacial outburst floods; dam breaching mechanisms; dam-breach models; flood routing models

Citation: ZHANG Xiujuan, LIU Shiyin. 2015. A framework of numerical simulation on moraine-dammed glacial lake outburst floods. Journal of Arid Land, 7(6): 728-740. doi: 10.1007/s40333-015-0133-x

In the context of climate change, increased natural hazards in vulnerable regions, including glacier lake outburst floods (GLOFs), ice avalanches, and debris-derived landslides, are of special concern in high mountainous areas of the world (Vaughan et al., 2013). Floods in alpine areas, especially moraine-dammed GLOFs, may be the most dangerous.

The assessment of GLOF risk is of great importance for the local residents and other stakeholders in areas where many glacial lakes have been formed or have expanded. The risk assessments of GLOF events normally include a detailed survey and modeling of the movement and calving processes of the glacier front, glacier lake water storage and change, debris slope failure, and ice avalanches. Several hydraulic models have been used in modeling the hydrological processes of GLOFs in a wide range of areas from the Himalayas to the Andes in South America (Wang, 2008; Tie and Tang, 2009). It is always very challenging into coupling the processes related to moraine dams with ice cores, outlet erosion, seepage, and/or piping while modeling the flood evolution, especially for remote alpine regions like the Poiqu River Basin, which is an important trading port between China and Nepal. Because the present models are, to some extent, modified from plain hydraulic floods, and there is a lack of quantitative GLOF risk assessment in the Poiqu River Basin, a framework aimed at GLOF modeling is highly necessary, considering the extreme vulnerability of social and economic sectors in the high mountains.

This paper summarized the commonly used dam-breach and flood propagation models, and presented a framework for the simulation and hazard mapping of GLOF disasters in the Poiqu River Basin in the Mount Everest region based on limited data and the knowledge of various GLOF mechanisms and the dam breach and hydrodynamic models. Meanwhile

*Corresponding author: ZHANG Xiujuan (E-mail: zhangxiujuan@lzb.ac.cn) Received 2015-01-22; revised 2015-05-07; accepted 2015-07-01

(C) Xinjiang Institute of Ecology and Geography, Chinese Academy of Sciences, Science Press and Springer-Verlag Berlin Heidelberg 2015 
the uncertainties and challenges in the GLOF model chain were discussed in detail.

\section{Models for moraine-dammed glacial lake outburst floods}

\subsection{Dam-breach models}

1.1.1 Empirical estimations for the peak discharge Various empirical equations, which represent simple statistical relationships among slope (S), lake area (A) or volume (V), water head $(\mathrm{H})$, and peak discharge (Qp), have been derived from experimental and historical case studies to estimate GLOF peak discharge (Table 1). These equations are not process-based during a dam failure but, rather, are derived from numerous historical dam failure records; accordingly, the breach initiation and dynamic hydraulic processes must be neglected. The application of these empirical equations should be careful to discriminate the dam types, the inherent materials, and the breach initiation conditions.

Table 1 Empirical equations for estimating the peak discharge of moraine-dammed lake outburst floods

\begin{tabular}{|c|c|c|c|}
\hline Method & Equation & Type & Reference \\
\hline \multirow[t]{2}{*}{ Slope-area } & $Q p=3.39 A^{1.3} S^{0.32}$ & Best fit & Riggs (1976) \\
\hline & $Q p=4 A^{1.21} S^{0.28}$ & Best fit & Williams (1978) \\
\hline \multirow[t]{3}{*}{ Height of water } & $Q p=60.3 H^{0.84}$ & Best fit & Walder and O’Connor (1997) \\
\hline & $Q p=0.784 H^{2.668}$ & Linear & Pierce et al. (2010) \\
\hline & $Q p=2.325 \ln (H)^{6.405}$ & Curvilinear & Pierce et al. (2010) \\
\hline \multirow[t]{3}{*}{ Storage } & $Q p=0.72 V^{0.53}$ & Best fit & Evans (1986) \\
\hline & $Q p=0.045 V^{0.66}$ & Best fit & Walder and O’Connor (1997) \\
\hline & $Q p=0.00919 V^{0.745}$ & Best fit & Pierce et al. (2010) \\
\hline \multirow[t]{6}{*}{ Height of water and storage } & $Q p=1.205(V H)^{0.48}$ & Envelope & Hagen (1982) \\
\hline & $Q p=1.154(V H)^{0.412}$ & Best fit & MacDonald and Langridge- Monopolis (1984) \\
\hline & $Q p=0.763(V H)^{0.42}$ & Best fit & Costa (1983) \\
\hline & $Q p=0.607\left(V^{0.295} H^{1.24}\right)$ & Best fit & Froehlich (1995) \\
\hline & $Q p=0.19(V H)^{0.47}$ & Best fit & Walder and O’Connor (1997) \\
\hline & $Q p=0.038\left(V^{0.475} H^{1.09}\right)$ & Best fit & Pierce et al. (2010) \\
\hline
\end{tabular}

\subsubsection{Parametric dam-breach models}

The early numerical model DAMBRK (Fread, 1977) developed by the U.S. National Weather Service (NWS) has been widely used to calculate breach outflow hydrographs. For instance, Meon and Schwarz (1993) used the DAMBRK model to simulate the progressive dam breach of Quangzonk Co Lake in the Natang River Basin, based on certain assumptions of breach shape and breach time after various sensitivity tests. Their study concluded that design floods of projects in glacier-dominated mountains should take GLOF analysis into consideration. The deterministic model BREACH, which was also developed by the NWS, is a physically based model that predicts the breach characteristics (size, time of formation) and the discharge hydrograph emanating from a breached earthen dam. Bajracharya et al. (2007) used the BREACH model to simulate the outburst hydrographs of a dam breach at Dig Tsho Lake and Imja Lake in the Sagarmatha region of Nepal, which required the geometry and geotechnical parameters of the dam and the lakes as the inputs, although the peak outflow was significantly larger than those in earlier studies by Cenderelli and Wohl $(2001,2003)$ that had used HEC-RAS due to different methodologies and assumptions. It should be noted that parametric dam breach models hindered the accurate simulation of the dam breach processes by not considering the actual breach initiation and detailed materials of the dam, which prompted the advent of the physically based dam breaching models.

1.1.3 Physically based dam-breach numerical models Completely physically based numerical models have not been widely used in the GLOF literature due to their complexity, lack of data, and the computational cost. Moreover, such numerical models are based on 
complex physical processes, such as the breach initiation, morphology and location, and the hydraulics and sediment transport of the flow, and they also incorporate data for calibration and verification (Mohamed et al., 2002). With the advent of advanced computers, the purely physical numerical models will become more common in the future.

\subsection{Flood routing simulation}

1.2.1 Paleohydraulic technologies for GLOF reconstruction

Paleohydraulic reconstruction, the earliest hydraulic technique, is based upon the empirical combination of flow regime, channel morphology, peak discharge, and water velocity and depth, further based on the assumptions of steady and uniform flow, fully submerged particles, and temporally constant hydraulic variables (Costa, 1983). In fact, GLOFs are unsteady, complex, and varying flows, which are characterized as different flow regimes, sediment transport, and flood phases (Kershaw et al., 2005). This kind of deterministic approach may be used when the additional calibration and verification data for the glacial lakes that were lacking due to the remote locations and paleo outburst floods becomes available.

\subsubsection{GIS-based flow routing models}

GIS-based flow routing models are simple and effective to simulate flows based on the digital elevation models (DEMs) at the regional scale in high mountain areas (Tarboton, 1997; Huggel et al., 2004). Huggel et al. (2003) applied two topography-based GIS models simulating glacial lake outburst debris flows, a modified single flow direction model (MSF), and a multiple flow direction model (MF) on three different DEMs in the Swiss Alps without consideration of bridges, armored channels, or buildings. Allen et al. (2009) integrated remote sensing-based terrain mapping, GIS, and MSF to explore the extent of ice avalanches, debris flows and lake flood hazard potential in the Mount Cook region of New Zealand's Southern Alps, which simplified the complex natural processes and is useful for investigations and integration into GIS and RS. Even though these GIS-based models are generally applicable to gravitational flows of the natural hazards in larger regions, there are no physical bases to represent more complex mass movements and the con- siderable assumptions can constrict the simulation.

\subsubsection{Physically based flow routing models}

The physically based flow routing models can be classified as 1-D, 2-D, and 3-D. In general, 1-D numerical models are based on one-dimensional Saint-Venant or shallow water equation (SWE), and usually apply the step-backwater procedure (Westoby et al., 2014a):

$$
\begin{gathered}
\frac{\partial A}{\partial t}+\frac{\partial Q}{\partial x}=0 \\
\frac{1}{A} \frac{\partial Q}{\partial t}+\frac{1}{A} \frac{\partial}{\partial x}\left(\frac{Q^{2}}{A}\right)+g \frac{\partial h}{\partial x}-g\left(S_{0}-S_{f}\right)=0 .
\end{gathered}
$$

The conservation of mass and momentum equations are Eq. 1 and Eq. 2, respectively, wherein $A$ is the surface area of the cross-section, $Q$ is the flow discharge, $t$ is time, $g$ is gravitational acceleration, $h$ is the water depth of the cross-section, $S_{0}$ is the longitudinal bed slope, and $S_{f}$ is the friction slope.

2-D numerical models are based on depth-averaged SWE derived by the Reynolds-averaged Navier-Stokes equations (Worni et al., 2012):

$$
\begin{gathered}
\frac{\partial h}{\partial t}+\frac{\partial(u h)}{\partial x}+\frac{\partial(v h)}{\partial y}=0 . \\
\frac{\partial u}{\partial t}+u \frac{\partial u}{\partial x}+v \frac{\partial u}{\partial y}+g \frac{\partial h}{\partial x}=-g \frac{\partial z_{B}}{\partial x}-\frac{1}{\rho h} \tau_{B x}+ \\
\frac{1}{\rho h} \frac{\partial\left[h\left(\tau_{x x}+D_{x x}\right)\right]}{\partial x}+\frac{1}{\rho h} \frac{\partial\left[h\left(\tau_{x y}+D_{x y}\right)\right]}{\partial y} . \\
\frac{\partial v}{\partial t}+u \frac{\partial v}{\partial x}+v \frac{\partial v}{\partial y}+g \frac{\partial h}{\partial y}=-g \frac{\partial z_{B}}{\partial y}-\frac{1}{\rho h} \tau_{B y}+ \\
\frac{1}{\rho h} \frac{\partial\left[h\left(\tau_{y x}+D_{y x}\right)\right]}{\partial x}+\frac{1}{\rho h} \frac{\partial\left[h\left(\tau_{y y}+D_{y y}\right)\right]}{\partial y} .
\end{gathered}
$$

Where $h$ is the water depth, $u$ and $v$ are the flow velocity in the $x$ direction and $y$ direction, respectively, $t$ is time, $g$ is gravitational acceleration, $\rho$ is the fluid density, $\tau_{B x}$ and $\tau_{B y}$ are the bed shear stresses in the $x$ direction and $y$ direction, respectively, $z_{B}$ is the bottom elevation, $\tau_{x x}, \tau_{x y}, \tau_{y x}$, and $\tau_{y y}$ are depth-averaged viscous turbulent stresses, and $D_{x x}, D_{x y}, D_{y x}$, and $D_{y y}$ are the momentum dispersion terms.

3-D numerical models are based on the full Navier-Stokes equations, and calculate flow velocities across both the flow width and depth; however, applications of fully 3-D numerical models are rarely used. 
Table 2 Different physically based numerical models for simulating flood propagation processes

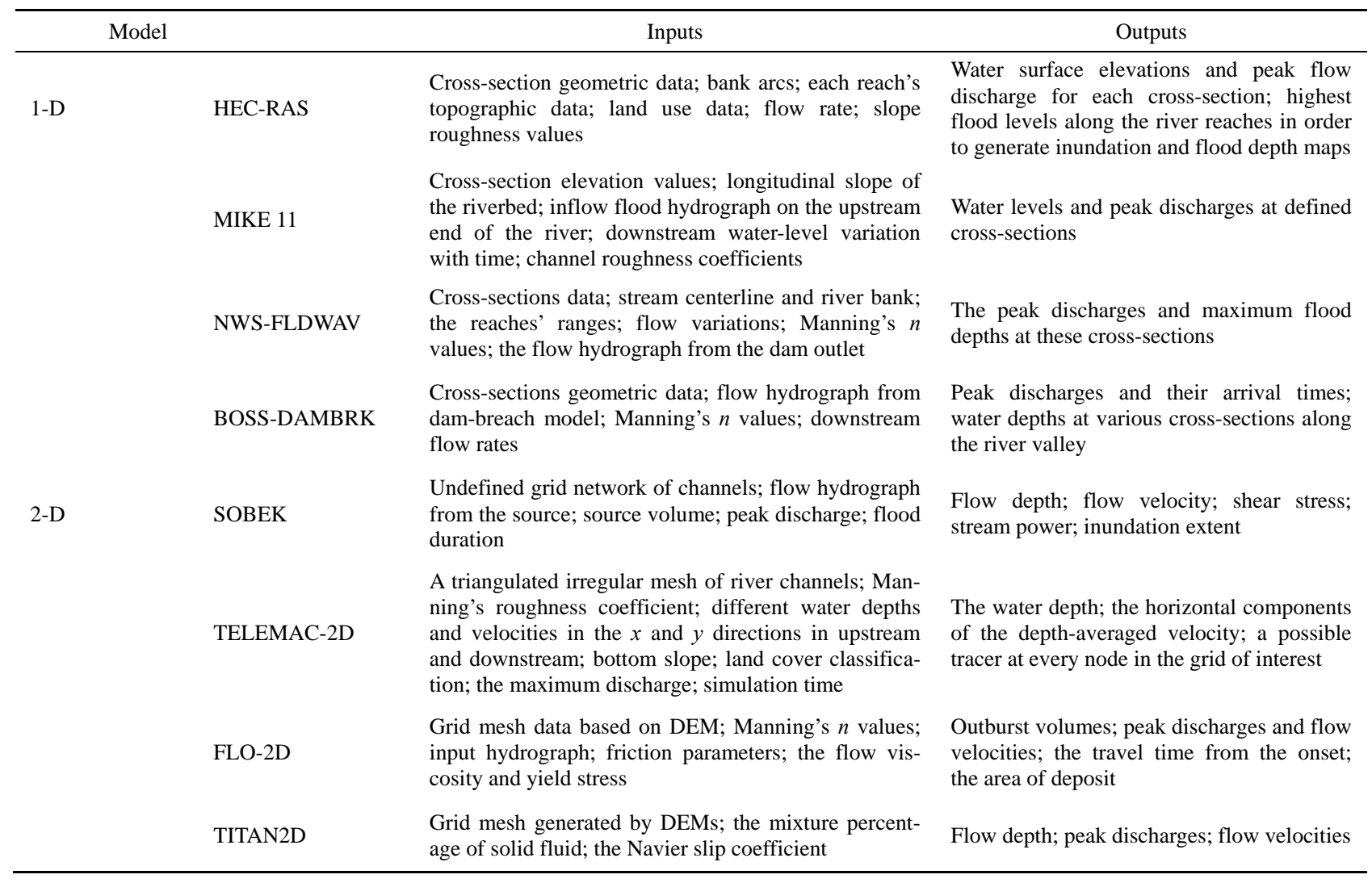

The commonly used 1-D numerical models are HEC-RAS (Cenderelli and Wohl, 2001; Omer et al., 2003; Alho et al., 2007; Goodell and Brunner, 2008; Cook and Merwade, 2009; USACE, 2010; Wang et al., 2012a; Byers et al., 2013), MIKE 11 (Patro et al., 2009; Pramanik et al., 2010; Jain et al., 2012), NWS-FLDWAV (Bajracharya et al., 2007), and BOSS-DAMBRK (Shrestha et al., 2010). Currently, 2-D numerical models are commonplace but 3-D numerical models are rarely used to simulate GLOFs. Carrivick (2006) applied a 2-D hydrodynamic model, SOBEK, to reconstruct the fluvial flow characteristics of a high-magnitude outburst flood within an anastomosing network of simultaneously inundated channels, with the assumptions of a fixed channel bed, partial sediment transport, and premature bed elevation change. Alho and Aaltonen (2008) compared the capability of a 1-D HEC-RAS jökulhlaup simulation in Northeast Iceland with a 2-D finite element model TELEMAC-2D, using a pre-defined hydrograph. Their results indicated that unsteady HEC-RAS modelling is feasible to a ca. 200-m horizontal accuracy in the simple routes at the peak discharge stage, but the 2-D model could be used for non-parallel gorges of the main channel. Mergili et al. (2011) compared RAMMS as a mass movement model and FLO-2D using an input hydrograph as a river hydraulics model for predicting the motion of potential future GLOFs in the Pamir Mountains of Tajikistan. They found that RAMMS predicted higher flow depths and smaller inundation areas in the uppermost section than did FLO-2D, and that RAMMS predicted the stop of the flow and the deposition but FLO-2D tended to predict a continuation of the flow. Worni et al. (2012) applied the dynamic erosion-based dam break model BASEMENT to reconstruct the moraine breaching and flood propagation processes of the Ventisquero Negro GLOF in the Patagonian Andes in Argentina in May 2009. This provided detailed information on dam-breach processes that was largely consistent with field evidence, and thus was valuable for hazard assessments considering the parameter uncertainties and the need for careful calibration. They suggested that this model could be implemented systematically to 
define outburst scenarios. Pitman et al. (2013) extended the TITAN2D simulation environment originally developed for volcanic hazard computations to simulate the dynamics of GLOFs. This two-phase model of fluid and granular material flows was based on a hyperbolic system of balance laws using a Godunov solver on Davis's scheme, an adaptive mesh algorithm for refinements near the front and at regions of rapid change, and parallel processing, over the natural terrain of Lugge Lake in the Lunana region of Bhutan.

\section{Framework for reconstructing floods of moraine-dammed glacial lakes}

\subsection{Study site}

The Poiqu River, a tributary of the Ganges River, is located in the central-western Himalaya Mountains. It sources near Porong town and flows into the Indian Ocean. It covers an area of 2,026 $\mathrm{km}^{2}$ with a length of $445 \mathrm{~km}$, an annual mean discharge of $31.7 \mathrm{~m}^{3} / \mathrm{s}$, and a mean depth of $0.5 \mathrm{~m}$ (Xu, 1988; Xiang et al., 2014). The important branches of the Poiqu River Basin are the Rujiapu, Keyapu, Tajilingpu, Chongduipu, and Zhangzangbo rivers, which run, respectively, from the north to the south where most of the moraine-dammed glacial lakes are located. Thus, they pose significant threats to the local people's lives and the ecological environment (Fig. 1). According to data from the Nyalam meteorological station obtained from 1974 to 2013, the annual mean temperature is $3.81^{\circ} \mathrm{C}$, the annual mean temperature trend is $0.029^{\circ} \mathrm{C}$, the mean annual precipitation is $652.5 \mathrm{~mm}$, and the annual mean precipitation trend is $-1.955 \mathrm{~mm}$. There have been three GLOFs in the Poiqu River Basin: Lake Taraco (No. 35; 28 August 1935), Lake Cirenmaco (No. 42; 11 July 1981), and Lake Jialongco (No. 5; 23 May 2002 and 29 June 2002).

\subsection{Dam breach initiation}

Previous studies indicated that many historical moraine-dammed glacial lake outbursts were the result of overtopping waves generated by numerous natural events such as ice, snow, rock avalanches, and glacier calving (Blown and Church, 1985; Clague and Evans, 2000; Richardson and Reynolds, 2000). In principle,

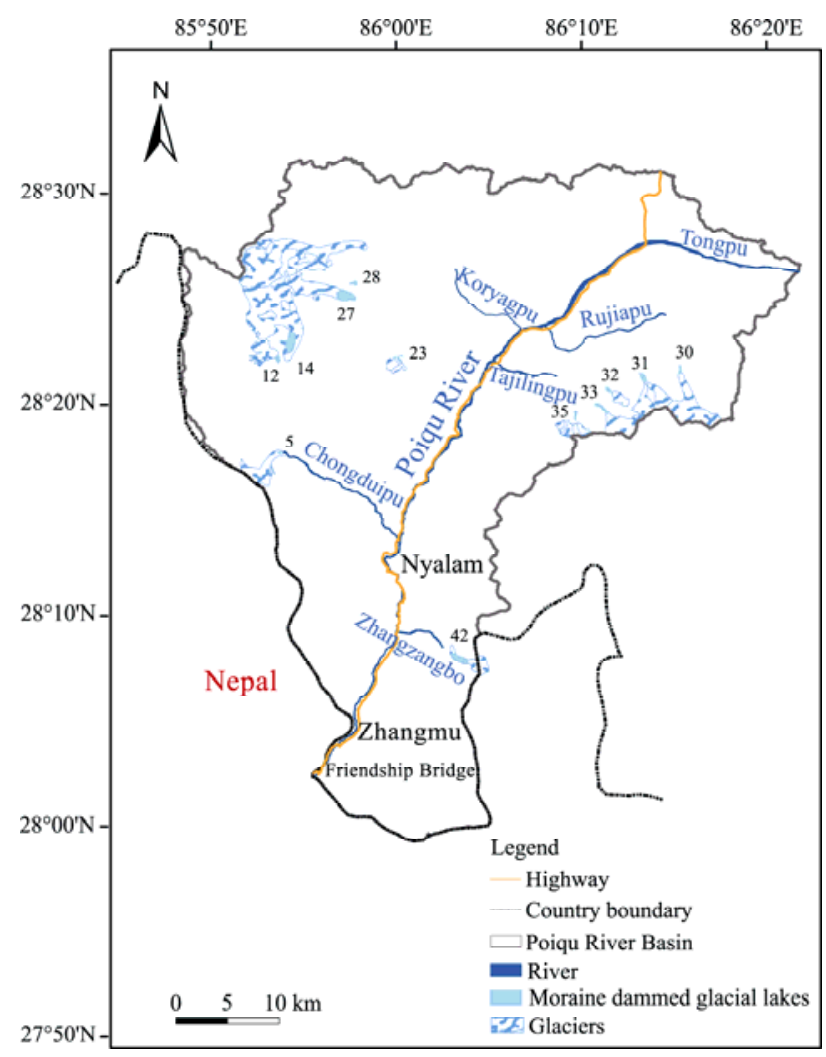

Fig. 1 Location of Poiqu River Basin and distribution of moraine-dammed glacial lakes (indicated by Arabic numerals) and their source glaciers

based on the analyzed mechanism of dam breaching, three different specific failure process scenarios of overtopping triggers are possible: 1 ) the bearing pressure of the partial dam is exceeded by driving forces induced by the seiche waves, causing the partial dam collapse (Hubbard et al., 2005); 2) seepage forces and shear stresses resulting from sloshing overtopping flow caused by ice, snow, or rock avalanches lead to the destabilization of the dam (Reynolds, 1992); and/or 3) repeated displacement waves triggered by small ice avalanches progressively erode the moraine dam, enlarge the breach, and weaken the dam structure until the dam finally collapses (Balmforth et al., 2008).

The delineation of piping and seepage in a moraine dam is rarely evident to the observer, due to the long duration from normal subdued outflow to cloudy seepage (Fell et al., 2003). Once the cloudy seepage suddenly begins, the overlying dam moraine collapses and subsequent erosion by the overtopping waves leads to the dam failure (Mohamed et al., 2002). 


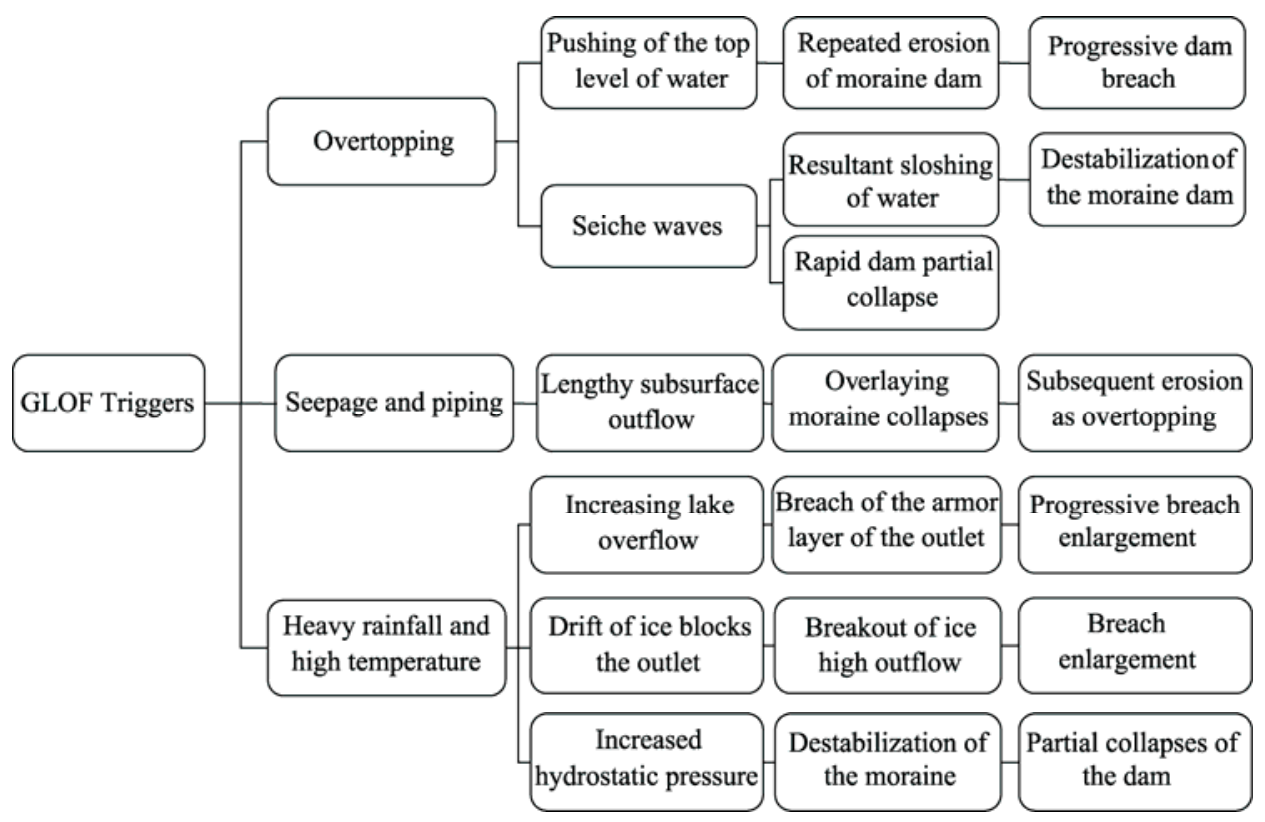

Fig. 2 Illustration of different scenarios and processes of historical moraine dam breaches triggered by different mechanisms

Atmospheric triggers such as heavy precipitation and high temperatures (Huggel et al., 2002) may increase the lake water level or the drift of ice blocks, which then causes the dam failure. According to Worni et al. (2012), three different failure scenarios can ensue: 1) after heavy precipitation leads to enough increased lake overflow to erode the dam vertically, the increased lake outflow results in the expansion of the dam breach; 2) the drift of ice blocks in the lake caused by the high water level and outflows can plug the outlet, resulting in higher water level and water pressure, which may in turn uproot the plugged ice blocks, initiate erosion, and then continue the breach expansion; and/or 3) increasing hydrostatic pressure due to the rising water level of the lake may cause instability of the ice core in a moraine dam, which could break apart or uplift or melt, leading to the destabilization of the dam.

\subsection{GLOFs numerical modelling}

Based on Section 1.2, we can summarize a general framework for GLOF simulations and hazard mapping. First, the data preparation, including photographs and satellite images of the study site, digital terrain models (DTMs) of the lake or lake bathymetry, the river channel and the floodplain, and sediment and geomorphological observation of the dam and the river bank, is a difficult but necessary and important step for the subsequent numerical simulations. Because few researchers pay attention to the breach initiation phase, a hydrograph of the dam breach or empirical equations of the peak discharge are usually used as the initial condition (Osti and Egashira, 2009; Alho et al., 2010; Somos-Valenzuela and McKinney, 2011; Petrakov et al., 2012; Osti et al., 2013) instead of measurements of the dam geometry and trigger mechanisms. This is why there is often a lack of pre-GLOF high-resolution photographs or satellite imagery as well as observed meteorological and hydrological data for model calibration or validation. The parameters that were used in numerical simulation of GLOFs by several researchers (Bajracharya et al., 2007; Shrestha et al., 2010; Worni et al., 2012; Westoby et al., 2014b) are summarized in Table 3.

Second, a fully physically based dam breach model is applied to simulate the breach development and the hydrograph, which requires accurate parameterization to define the initial and boundary conditions based on the data prepared by field observation, photogrammetry, numerous DEMs and satellite images. For example, the 2-D numerical model BASEMENT, a novel, dual-mesh approach with separate meshes for hydraulic and sediment calculations based on the vertical dam erosion, uses empirical sediment transport 
Table 3 Model input parameters and data sources used for numerical simulations of GLOF

\begin{tabular}{lll}
\hline Parameter & Description & Data source \\
\hline Lake surface area & The area of the lake $\left(\mathrm{km}^{2}\right)$ & Field measurement or images \\
Dam foundation level & The elevation of the dam foundation $(\mathrm{m})$ & Field measurement or DTM \\
Crest level & The elevation of the dam crest $(\mathrm{m})$ & Field measurement or DTM \\
Crest length & The length of the dam crest $(\mathrm{m})$ & Field measurement or DTM \\
Crest width & The width of the dam crest $(\mathrm{m})$ & Field measurement or DTM \\
Distal face slope & The slope of the dam's distal face $\left(^{\circ}\right)$ & Field measurement or DTM \\
Proximal face slope & The slope of the proximal face $\left(^{\circ}\right)$ & Field measurement or DTM \\
Valley slope & The slope of the downstream valley $\left({ }^{\circ}\right)$ & Field measurement or DEM \\
Sediment flow factor & Linear multiplication of transport capacity & Parameter sampling calibration \\
Erosion width-to-depth ratio & The ratio of the width to the depth of dam breach $(\%)$ & Parameter sampling calibration \\
D50 diameter & The diameter of the material D50 $(\mathrm{mm})$ & Parameter sampling calibration \\
D90/D30 & The ratio of the material D90 to D30 $(\%)$ & Parameter sampling calibration \\
Porosity & General bed material porosity $(\%)$ & Parameter sampling calibration \\
Density & Fluid density $\left(\mathrm{kg} / \mathrm{m}^{3}\right)$ & Parameter sampling calibration \\
Manning's $n$ & Resistance factor and internal energy dissipation $\left(\mathrm{s} / \mathrm{m}^{1 / 3}\right)$ & Field measurement or material constant \\
Internal angle of friction & The critical angle of the slope failure $\left(^{\circ}\right)$ & Parameter sampling calibration \\
Cohesion & Soil cohesion of the dam and river bank $\left(\mathrm{kg} / \mathrm{m}^{2}\right)$ & Parameter sampling calibration \\
Mixture of dam moraine & Fraction of each grain class $\left({ }^{\circ}\right)$ & Field measurement \\
Failure angle below water surface & Angle of the slope failure when below water $\left({ }^{\circ}\right)$ & Field measurement or DTM \\
Failure angle above water surface & Angle of the slope failure when above water $\left({ }^{\circ}\right)$ & Field measurement or DTM \\
\hline
\end{tabular}

formulas and the lateral widening process via a geometrical approach (Volz et al., 2010). As mentioned earlier, Worni et al. (2012) used this model to investigate the breaching processes and then to reconstruct the dam breach trigger, the breaching, and the lake emptying processes of the Ventisquero Negro GLOF in the Patagonian Andes; and the model reproduced the lake outflow hydrograph accurately and was consistent with field evidence. Another numerical dam-breach model, HR BREACH, can predict the progressive growth of a dam breach initiated by either overtopping or piping through the interaction of continuous hydraulic erosion, based on equilibrium sediment transport equations or erosion depth equations, and discrete mass failures as a consequence of side slope instability. Westoby et al. (2015) applied HR BREACH to reconstruct the failure at Dig Tsho Lake in Nepal due to overtopping waves generated by an ice avalanche in a scenario-specific behavioral simulation. However, given the limits of HR BREACH on the simulation of explosive or rapid, large-scale rotational mass failure, and the simplicity of the geometric and material characteristics of a moraine and lake complex, breach morphology is also reproducible by its stochastic parameter sampling functionality.

In the third step, the breach hydrograph is used as the hydraulic initiation condition for a 2-D or higher-dimensional hydrodynamic model based on the mesh grid generated by the river channel and the floodplain DTMs with the roughness coefficients. Considering the outburst flood waves of moraine-dammed glacial lakes eroding soil and entraining gravels and rocks together with flows as fast as tens of meters per second and tens of kilometers of propagate distances, mass and momentum balance laws and the equations of mixture theory are utilized during the numerical simulations. For example, Pitman et al. (2013) developed a system of mass and momentum balance laws for a "thin-layer" model for the mixture of liquid and granular material to extend the TITAN2D simulation environment, which simulated a GLOF of Lugge Lake in Bhutan and demonstrated the robustness and efficiency of a two-phase model. The governing equations of total mass balance are depth-averaged, with the assumption of a Mohr-Coulomb plastic solid as the granular material 
and inviscid fluid as the Navier slip to approximate the no-slip condition for a fluid flow over a rough surface.

Finally, in the specific context of the Poiqu River Basin, the social-economic index of the basin area would be added into the output inundation maps with the water depth, velocity, discharge, and the deposits to compile the GLOF hazard maps to be used for the future hazard mitigation policies and measures (Fig. 3). Westoby et al. (2014c) produced the flood hazard maps of Dig Tsho conditioned by flow depth and ve- locity as the indicators of hazard. A global hazard index was proposed by Aronica et al. (2012), who defined and shaded four hazard classes. Reynolds International Ltd (2014) produced a vulnerability assessment of glacial flood hazards in terms of natural vulnerabilities such as unconsolidated sediments, flow volume and discharge, water depth above river level, and secondary landslides, as well as human vulnerabilities including economic, social, ecological, organizational, educational, attitudinal, political, cultural, and physical aspects.

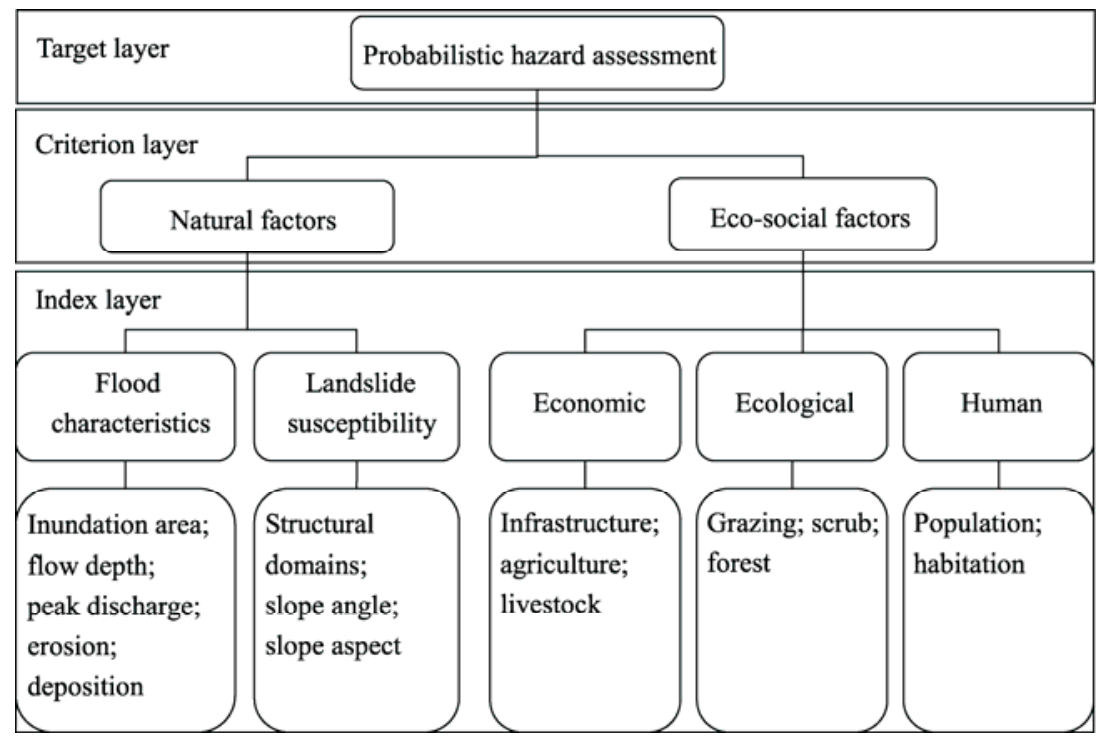

Fig. 3 Diagram of probabilistic hazard assessment of moraine-dammed glacial lake outburst floods

\section{Uncertainties and challenges in the GLOF reconstruction}

\subsection{Uncertainties related to DEMs}

There are a number of uncertainties in using DTMs based on photogrammetry or satellite images to reconstruct pre-existing moraine, lake, river channel, and floodplain topography and extraction of glacial lake bathymetry and dam geometry data. They are summarized in Table 4.

Although numerous DEMs of lakes and downstream valleys using different construction methods are shown in Table 4, the extraction of accurate characteristics of moraine dams, lake geometry, and material distribution still requires labor-intensive fieldwork (Hanson and Cook, 2004; Osti et al., 2011; Worni et al., 2012; Westoby et al., 2014d). Although various DEMs have been proven to be a crucial factor in numerical simulation of GLOFs, they should be used cautiously, considering the potential overestimation or underestimation of flood risks in the context of flood reconstruction or prediction. The detailed impacts of certain DEMs on the uncertainties of GLOF model chains and the measures to solve them are summarized in Table 5.

\subsection{Sensitivity analysis of parameters}

In the absence of any prior information regarding parameter and range choice, the uncertainty of establishing the input parameters and their respective ranges is unavoidable, but sensitivity analysis can help to constrain it. For instance, in Capart's (2013) analytically derived solutions, power laws for the peak 
Table 4 Comparison of DEMs used in simulations on dam breaching and flood propagation processes of GLOFs

\begin{tabular}{lll}
\hline Model & Name & \multicolumn{1}{c}{ Data source } \\
MF & DHM25 & $\begin{array}{l}\text { The } 25 \text { m-gridded DHM25, Level 2, } \\
\text { is a commercially available DEM } \\
\text { distributed by the Swiss Federal } \\
\text { Office of Topography }\end{array}$ \\
ASTER DEM & $\begin{array}{l}\text { The stereo image of ASTER sensor } \\
\text { onboard Terra } \\
\text { Aerial } \\
\text { photography }\end{array}$ & $\begin{array}{l}\text { The aerial photographs were taken in } \\
\text { 1999 at a scale of about 1:20,000; } \\
\text { Analytically extracted terrain break } \\
\text { lines were integrated in the process } \\
\text { of DEM generation }\end{array}$ \\
&
\end{tabular}

HEC-RAS

BreZo

1D HEC-RAS

2D FESWMS

30 m USGS

10 m USGS

GPS survey and bathymetry

Trimble 4,700 inematic differentia GPS in RTK mode; the river channel bottom was surveyed using a Navisound 50 echosound device

LiDAR

Vectorial cartography $(1: 5,000)$

IfSAR

SRTM

NED

The 1-m DTM was derived from LiDAR data using Optech ALTM 3025

Digital contour map with 5-m contour intervals supplied by the ICC (BT-5M)

Airborne interferometric synthetic aperture radar data at $1 / 9 \mathrm{~s}$ resolution

Shuttle radar topography mission data at 1 and 3 s resolution

From USGS quadrangle maps to LiDAR surveys at $1 / 3$ and $1 \mathrm{~s}$ resolution, which were processed with hydrologic modeling in mind

Integration of surveyed river cross-sections with National Elevation Dataset. Due to the narrow width of the Strouds Creek $(9.5 \mathrm{~m})$, the 10 and $30 \mathrm{~m}$ DEMs are re-sampled to a higher resolution

$6 \mathrm{~m}$ LiDAR Because of its inability to penetrate water, LiDAR data are integrated with surveyed cross-sections of bed topography

RAMMS

FLO-2D

SRTM DEM 90 m resolution

CORONADEM 10 and 20 m DEMs derived from CORONA imagery

HEC-RAS ASTER GDEM Validated against GPS points SRTM

Result Reference

The aerial photogrammetrically generated DEM with the Huggel et

highest degree of terrain detail may only be applicable al. (2003)

for certain local-scale studies. The 25 m-gridded DEM (DHM25) is suited for regional hazard assessments in the Swiss Alps, due to its high quality. The ASTER-derived DEM is suggested for model application in remote and poorly documented high-mountain regions worldwide.

A clear tendency of increasing flooded area as the reso- Casas et al. lution of the topography decreases. There are large dif- (2006)

ferences between the estimation of the flooded areas with a GPS- or laser-based terrain model and that obtained with a contour-based model, which highlight the latter's unsuitability for the accurate estimation of flooded area. The estimation of the flooded area shows variations of up to $50 \%$ for a contour-based model when compared to the laser-optimized DTM. The GPS-based model generates variations of up to $8 \%$ due to the interpolation between cross-sections in representing the floodplain, while optimized laser- and contour-based models vary by less than $1 \%$.

In the Santa Clara River application, flood simulation Sanders with airborne IfSAR was not possible because Inter- (2007) state- 5 was resolved by the DSM and acted like a dam across the river. DEMs based on 1 and 3 s STRM may have data gaps caused by radar shadow. Santa Clara River was only $200 \mathrm{~m}$ wide in places (ca. 7 s) and SRTM data yielded flood zone predictions only 25\% different than NED. Further, predictions based on 1-s SRTM yielded only slightly more accurate flood zones than predictions based on $3 \mathrm{~s}$ SRTM.

For a given flow and geometric description, the predict- Cook and ed area of flood inundation decreases with higher spatial Merwade resolution and vertical accuracy of topographic data. The (2009) area of inundation for Strouds Creek and Brazos decreased significantly for all topographic datasets (USGS and LIDAR) after river bathymetry is incorporated into topographic data. The percentage reduction in area for Strouds Creek is 33(24), 17(16) and 16(12) in percentage for $30 \mathrm{~m}$ USGS, $10 \mathrm{~m}$ USGS and $6 \mathrm{~m}$ LIDAR DEM using HEC-RAS (FESWMS). The percentage reduction in area for Brazos River reach is 7(1), 7(1) and 18(6) for USGS $30 \mathrm{~m}$, USGS $10 \mathrm{~m}$ and LIDAR DEM using HEC-RAS (FESWMS).

The velocities and the extent of spreading in the area of Mergili et deposit were larger when using the SRTM DEM al. (2011) (smoother terrain). The simulated travel time from the onset of the flow to the village was 55 minutes with the SRTM DEM and 76 minutes with the CORONA DEM.

Flood zone 2.2\% larger; water depths $2.3 \mathrm{~m}$ deeper Wang et al. based on GDEM; flood zone 6.8\% larger; $2.4 \mathrm{~m}$ shal- (2012b) lower based on SRTM than the base topographic data 
Table 5 Impact of DEMs on the uncertainties in GLOF simulations and the measures to solve them

\begin{tabular}{lll}
\hline \multicolumn{1}{c}{ Aspect } & \multicolumn{1}{c}{ Impact } & \multicolumn{1}{c}{ Solution } \\
\hline Trigger mechanism & $\begin{array}{l}\text { The identification of potential rock or snow ava- } \\
\text { lanche zones for setting the initial conditions }\end{array}$ & $\begin{array}{l}\text { Multi-temporal satellite images and fieldwork or stereo imag- } \\
\text { es-based topography to quantify }\end{array}$ \\
Moraine dam characteristics & $\begin{array}{l}\text { Dam geometry (height, width, upstream and } \\
\text { downstream slopes); dam breach development and } \\
\text { geometry; presence of ice core in moraine dams }\end{array}$ & $\begin{array}{l}\text { images together with DEMs based on photogrammetry in situ } \\
\text { or stere images; geophysical observation of intact moraine } \\
\text { dam by GPR or SAR, maybe visual analysis in situ }\end{array}$ \\
Lake geometry & $\begin{array}{l}\text { Lake area, depth, and volume, which determine } \\
\text { water pressure head and inflow }\end{array}$ & $\begin{array}{l}\text { Lake bathymetric survey (e.g. high-resolution echo sounder); } \\
\text { photogrammetry or DTM of lake basin }\end{array}$ \\
Grid mesh & $\begin{array}{l}\text { Decreasing the spatial resolution to keep smooth- } \\
\text { ing the grid mesh elements or distinguish the } \\
\text { flooded or non-flooded areas to minimize compu- } \\
\text { ting time }\end{array}$ & \\
\hline
\end{tabular}

discharge, time of peak, final breach drop, and transition distance where the flood peak begins to attenuate were included. His study determined that peak discharge was sensitive to the lake surface area, and was highly sensitive to the initial angle of the upstream dam face. Alho et al. (2010) undertook simple sensitivity tests on Manning's $n$ value, which was set as $0.01,0.05,0.10,0.20$, and 0.50 during rising and peak discharge stages, validating them with the specific hydrograph. In the sensitivity analysis of Worni et al. (2012), the model parameters were tested by varying their values in a reasonable range but keeping all other parameters at default; their influence on the modeled discharge and erosion indicated that Manning's $n$ value, material porosity, bedload factor, failure angle below the water surface, and the failure angle of deposition were highly sensitive, while the fluid density, grain class of the bed or dam material, and the density of the bedload were less sensitive.

The base topography and the observed flow process are dynamic within a floodplain, which is a post-reaction of the contemporary pathway rather than a true reflection of the features of the unexpected GLOFs. Reconstruction of actual GLOFs based on the understanding of other flood characteristics is inevitable in the absence of pre-GLOF topographic data and post-GLOF validation data, especially in rural alpine regions lacking measured data or proper satellite images and DEMs.

\subsection{Challenges in future GLOF research}

The challenges in future GLOF research include: (1) Future experimental and numerical observation within the conjunctions of seismic activity, the geo-technical characteristics of moraine dams and the influences of spatially continuous or discontinuous ice cores in the moraine dams, especially for their influence in triggering mechanism settings as well as serious structural failure and dam breach initiation; (2) The capabilities of dam breach models depend on synthetic and real-time geometric data and topography as input, parameterization based on scenario settings, and validation by observed moraine dam geometry or hydrography at the breach, which implies that accurate and proper data are crucial. Therefore, the scenario settings, the choice of model type, and the parameters should be carefully investigated, and relatively complete documentations of flood events are also important; (3) The widely used numerical models are capable of simulating spatio-temporally transitory flow characteristics but are most constrained by simplified erosion equations and solutions of the dynamic bed and front wave; and (4) Coupling of the dam breaching models and flood propagation models should pay attention to processing much necessary iteration especially when the results and parameters from one model can serve as the input for the other one.

\section{Conclusions}

Alpine or high-altitude outburst floods from impounded glacial lakes tend to be relatively complicated, multi-stage catastrophes, capable of causing significant geomorphologic changes in channel- and valley-floor floodplain surroundings and posing severe threats to infrastructure and the safety and livelihoods of human communities. In order to review the ele- 
ments of GLOFs comprehensively and synthetically, we here summarized different triggering mechanisms and cascading moraine dam breaching scenarios, and presented dam breach models and flood routing simulation models which are commonly employed to reconstruct or forecast GLOF dynamics. Our framework for the probabilistic GLOF simulation in the Poiqu River Basin provides the basis for future research. The first step in this framework is the data preparation, including photographs and satellite images of the study site, digital terrain models, and sediment and geomorphological observations of the dam and the river bank. Second, fully physically based dam breach models such as BASEMENT or HR BREACH are applied to simulate the breach development and the hydrograph. This requires accurate parameterization to define the initial and boundary conditions based on the data prepared in the first step. Third, the breach hydrograph is used as the hydraulic initiation condition for 2-D or higher-dimensional hydrodynamic models such as TITAN2D, based on the mesh grid generated by the river channel and the floodplain's DTMs with the roughness coefficients. Finally, the social-economic index of the Poiqu River Basin would be added into the output inundation maps with the water depth, velocity, discharge, and the deposits to compile the GLOF hazard maps which would form the basis of future hazard mitigation policies and measures. However, the requirement to model GLOF hydrodynamics accurately and produce detailed GLOF inundation maps and hazard assessments must consider the uncertainty of the data processing and parameterization, model sensitivity and the coupling of dam breach models and hydrodynamic models. Also, the high computational cost for the implementation of high-quality 2-D and 3-D hydraulic models, as well as the relative paucity of sufficient-resolution topographic data, detailed characteristics of pre-flood moraine dams and glacial lakes, and discretization of valleys and floodplains are still the main challenges to the extensive application of these models for hazard and risk assessments of prospective GLOFs.

\section{Acknowledgements}

This work was funded by the National Key Technology Research and Development Program and the Key Basic Research
Program of the Ministry of Science and Technology of China (2012BAC19B07, 2013FY111400) and the National Natural Science Foundation of China (41190084).

\section{References}

Alho P, Roberts M J, Käyhkö J. 2007. Estimating the inundation area of a massive, hypothetical jökulhlaup from northwest Vatnajökull, Iceland. Natural Hazards, 41(1): 21-42.

Alho P, Aaltonen J. 2008. Comparing a 1D hydraulic model with a 2D hydraulic model for the simulation of extreme glacial outburst floods. Hydrological Processes, 22(10): 1537-1547.

Alho P, Baker V R, Smith L N. 2010. Paleohydraulic reconstruction of the largest Glacial Lake Missoula draining (s). Quaternary Science Reviews, 29(23-24): 3067-3078.

Allen S K, Schneider D, Owens I F. 2009. First approaches towards modelling glacial hazards in the Mount Cook region of New Zealand's Southern Alps. Natural Hazards and Earth System Sciences, 9(2): 481-499.

Aronica G T, Candela A, Fabio P, et al. 2012. Estimation of flood inundation probabilities using global hazard indexes based on hydrodynamic variables. Physics and Chemistry of the Earth, Parts A/B/C, 42-44: 119-129.

Bajracharya B, Shrestha A B, Rajbhandari L. 2007. Glacial lake outburst floods in the Sagarmatha region: Hazard assessment using GIS and hydrodynamic modeling. Mountain Research and Development, 27(4): 336-344.

Balmforth N J, von Hardenberg J, Provenzale A, et al. 2008. Dam breaking by wave-induced erosional incision. Journal of Geophysical Research, 113(F1): F01020.

Blown I G, Church M. 1985. Catastrophic lake drainage within the Homathko River basin, British Columbia. Canadian Geotechnical Journal, 22(4): 551-563.

Byers A C, McKinney D C, Somos-Valenzuela M, et al. 2013. Glacial lakes of the Hinku and Hongu valleys, Makalu Barun National Park and Buffer Zone, Nepal. Natural Hazards, 69(1): 115-139.

Capart H. 2013. Analytical solutions for gradual dam breaching and downstream river flooding. Water Resources Research, 49(4): 1968-1987.

Carrivick J L. 2006. Application of 2D hydrodynamic modelling to high-magnitude outburst floods: An example from Kverkfjöll, Iceland. Journal of Hydrology, 321(1-4): 187-199.

Casas A, Benito G, Thorndycraft V R, et al. 2006. The topographic data source of digital terrain models as a key element in the accuracy of hydraulic flood modelling. Earth Surface Processes and Landforms, 31(4): 444-456.

Cenderelli D A, Wohl E E. 2001. Peak discharge estimates of glacial-lake outburst floods and "normal" climatic floods in the Mount Everest region, Nepal. Geomorphology, 40(1-2): 57-90.

Cenderelli D A, Wohl E E. 2003. Flow hydraulics and geomorphic effects of glacial-lake outburst floods in the Mount Everest region, Nepal. Earth Surface Processes and Landforms, 28(4): 385-407.

Clague J J, Evans S G. 2000. A review of catastrophic drainage of moraine-dammed lakes in British Columbia. Quaternary Science Reviews, 19(17-18): 1763-1783. 
Cook A, Merwade V. 2009. Effect of topographic data, geometric configuration and modeling approach on flood inundation mapping. Journal of Hydrology, 377(1-2): 131-142.

Costa J E. 1983. Paleohydraulic reconstruction of flash-flood peaks from boulder deposits in the Colorado Front Range. The Geological Society of America Bulletin, 94(8): 986-1004.

Evans S F. 1986. The maximum discharge of outburst floods caused by the breaching of man-made and natural dams. Canadian Geotechnical Journal, 23(3): 385-387.

Fell R, Wan C F, Cyganiewicz J, et al. 2003. Time for development of internal erosion and piping in embankment dams. Journal of Geotechnical and Geoenvironmental Engineering, 129(4): 307-314.

Fread D L. 1977. The development and testing of a dam-break flood forecasting model. In: Proceedings of the Dam-Break Flood Routing Model Workshop. Washington D.C.: Water Resources Council, 164-197.

Froehlich D C. 1995. Peak outflow from breached embankment dam. Journal of Water Resources Planning and Management, 121(1): 90-97.

Goodell C R, Brunner G W. 2008. A dam breach model of epic proportions: Simulating the Glacial Lake Missoula floods. In: World Environmental and Water Resources Congress 2008: Ahupua'A. Rerston, VA: ASCE, 1-11.

Hagen V K. 1982. Re-evaluation of design floods and dam safety. In: Proceedings of the 14th Congress of International Commission on Large Dams, Rio de Janeiro, Brazil.

Hanson G J, Cook K R. 2004. Apparatus, test procedures, and analytical methods to measure soil erodibility in situ. Applied Engineering in Agriculture, 20(4): 455-462.

Hubbard B, Heald A, Reynolds J M, et al. 2005. Impact of a rock avalanche on a moraine-dammed proglacial lake: Laguna Safuna Alta, Cordillera Blanca, Peru. Earth Surface Processes and Landforms, 30(10): 1251-1264.

Huggel C, Kääb A, Haeberli W, et al. 2002. Remote sensing based assessment of hazards from glacier lake outbursts: A case study in the Swiss Alps. Canadian Geotechnical Journal, 39(2): 316-330.

Huggel C, Kääb A, Haeberli W, et al. 2003. Regional-scale GIS-models for assessment of hazards from glacier lake outbursts: Evaluation and application in the Swiss Alps. Natural Hazards and Earth System Sciences, 3(6): 647-662.

Huggel C, Kääb A, Salzmann N. 2004. GIS-based modeling of glacial hazards and their interactions using Landsat-TM and Ikonos imagery. Norsk Geografisk Tidsskrift-Norwegian Journal of Geography, 58(2): 61-73.

Jain S K, Lohani A K, Singh R D, et al. 2012. Glacial lakes and glacial lake outburst flood in a Himalayan basin using remote sensing and GIS. Natural Hazards, 62(3): 887-899.

Kershaw J A, Clague J J, Evans S G. 2005. Geomorphic and sedimentological signature of a two-phase outburst flood from moraine-dammed Queen Bess Lake, British Columbia, Canada. Earth Surface Processes and Landforms, 30(1): 1-25.

MacDonald T C, Langridge-Monopolis J. 1984. Breaching charateristics of dam failures. Journal of Hydraulic Engineering, 110(5): 567-586.

Meon G, Schwarz W. 1993. Estimation of Glacier Lake Outburst Flood and its impact on a hydro project in Nepal. In: Young G J. Proceedings of the International Symposium on Snow and Glacier Hydrology, IAHS Publication No. 218. Wallingford, England: IAHS, 331-340.

Mergili M, Schneider D, Worni R, et al. 2011. Glacial lake outburst floods in the Pamir of Tajikistan: Challenges in prediction and modelling. In: Proceeding of the 5th International Conference on Debris-Flow Hazards "Mitigation, Mechanics, Prediction and Assessment”. Italy: University of Padova, 6: 14-17.

Mohamed M A A, Samuels P G, Morris M W, et al. 2002. Improving the accuracy of prediction of breach formation through embankment dams and flood embankments. In: River Flow 2002: $1^{\text {st }}$ International Conference on Fluvial Hydraulics. Louvain-la-Neuve, Belgium.

Omer C R, Nelson E J, Zundel A K. 2003. Impact of varied data resolution on hydraulic modeling and floodplain delineation. Journal of the American Water Resources Association, 39(2): 467-475.

Osti R, Egashira S. 2009. Hydrodynamic characteristics of the Tam Pokhari Glacial Lake outburst flood in the Mt. Everest region, Nepal. Hydrological Processes, 23(20): 2943-2955.

Osti R, Bhattarai T N, Miyake K. 2011. Causes of catastrophic failure of Tam Pokhari moraine dam in the Mt. Everest region. Natural Hazards, 58(3): 1209-1223.

Osti R, Egashira S, Adikari Y. 2013. Prediction and assessment of multiple glacial lake outburst floods scenario in Pho Chu River basin, Bhutan. Hydrological Processes, 27(2): 262-274.

Patro S, Chatterjee C, Singh R, et al. 2009. Hydrodynamic modelling of a large flood-prone river system in India with limited data. Hydrological Processes, 23(19): 2774-2791.

Petrakov D A, Tutubalina O V, Aleinikov A A, et al. 2012. Monitoring of Bashkara Glacier lakes (Central Caucasus, Russia) and modelling of their potential outburst. Natural Hazards, 61(3): 1293-1316.

Pierce M W, Thornton C I, Abt S R. 2010. Predicting peak outflow from breached embankment dams. Journal of Hydrologic Engineering, 15(5): 338-349.

Pitman E B, Patra A K, Kumar D, et al. 2013. Two phase simulations of glacier lake outburst flows. Journal of Computational Science, 4(1-2): 71-79.

Pramanik N, Panda R K, Sen D. 2010. One dimensional hydrodynamic modeling of river flow using DEM extracted river cross-sections. Water Resources Management, 24(5): 835-852.

Reynolds J M. 1992. The identification and mitigation of glacier-related hazards: Examples from the Cordillera Blanca, Peru. In: McCall G J H, Laming D J C, Scott S C. Geohazards. Netherlands: Springer, 143-157.

Reynolds International Ltd. 2014. Development of glacial hazard and risk minimisation protocols in rural environments: guidelines for the management of glacial hazards and risks. In: Reynolds Geo-Sciences Ltd. Project No. R7816. Mold, Flintshire, UK.

Richardson S D, Reynolds J M. 2000. An overview of glacial hazards in the Himalayas. Quaternary International, 65-66: 31-47.

Riggs H C. 1976. A simplified slope-area method for estimating flood discharges in natural channels. Journal of Research US Geological Survey, 4: 285-291.

Sanders B F. 2007. Evaluation of on-line DEMs for flood inundation 
modeling. Advances in Water Resources, 30(8): 1831-1843.

Shrestha A B, Eriksson M, Mool P, et al. 2010. Glacial lake outburst flood risk assessment of Sun Koshi Basin, Nepal. Geomatics, Natural Hazards and Risk, 1(2): 157-169.

Somos-Valenzuela M, McKinney D C. 2011. Modeling a glacial lake outburst flood (GLOF) from Palcacocha Lake, Peru. The University of Texas at Austin: Center for Research in Water Resources.

Tarboton D G. 1997. A new method for the determination of flow directions and upslope areas in grid digital elevation models. Water Resources Research, 33(2): 309-319.

Tie Y B, Tang C. 2009. Progress in glacier lake outburst assessment system. Advances in Water Science, 20(3): 448-452. (in Chinese)

US Army Corps of Engineers (USACE). 2010. HEC-RAS River Analysis System: Applications Guide (Version 4.1). Davis, CA: Hydrologic Engineering Center, 790.

Vaughan D G, Comiso J C, Allison I, et al. 2013. Observations: Cryosphere. In: Stocker T F, Qin D, Plattner G K, et al. Climate Change 2013: The Physical Science Basis. Contribution of Working Group I to the Fifth Assessment Report of the Intergovernmental Panel on Climate Change. Cambridge, UK: Cambridge University Press.

Volz C, Rousselot P, Vetsch D, et al. 2010. Numerical modeling of dam breaching processes due to overtopping flow. In: Proceedings of 8th ICOLD European Club Symposium. Innsbruck, 691-696.

Walder J S, O’Connor J E. 1997. Methods for predicting peak discharge of floods caused by failure of natural and constructed earthen dams. Water Resources Research, 33(10): 2337-2348.

Wang W C, Yao T D, Yang W, et al. 2012a. Methods for assessing regional glacial lake variation and hazard in the southeastern Tibetan Plateau: A case study from the Boshula mountain range, China. Environmental Earth Sciences, 67(5): 1441-1450.

Wang W C, Yang X X, Yao T D. 2012b. Evaluation of ASTER GDEM and SRTM and their suitability in hydraulic modelling of a glacial lake outburst flood in southeast Tibet. Hydrological Processes, 26(2): 213-225.

Wang X. 2008. Methods and application for the hazard assessment of moraine dammed lake outburst floods in the Himalayas, China. $\mathrm{PhD}$ Dissertation. Beijing: Chinese Academy of Sciences. (in Chinese)

Westoby M J, Glasser N F, Brasington J, et al. 2014a. Modelling outburst floods from moraine-dammed glacial lakes. Earth-Science Reviews, 134: 137-159.

Westoby M J, Glasser N F, Hambrey M J, et al. 2014b. Reconstructing historic Glacial Lake Outburst Floods through numerical modelling and geomorphological assessment: Extreme events in the Himalaya. Earth Surface Processes and Landforms, 39(12): 1675-1692.

Westoby M J, Brasington J, Glasser N F, et al. 2014c. Numerical modelling of Glacial Lake Outburst Floods using physically based dam-breach models. Earth Surface Dynamics Discussions, 2(1): 477-533.

Westoby M J, Brasington J, Glasser N F, et al. 2014d. 'Structure-from-Motion' photogrammetry: A low-cost, effective tool for geoscience applications. Geomorphology, 179: 300-314.

Westoby M J, Brasington J, Glasser N F, et al. 2015. Numerical modelling of glacial lake outburst floods using physically based dam-breach models. Earth Surface Dynamics, 3(1): 171-199.

Williams G P. 1978. Bank-full discharge of rivers. Water Resources Research, 14(6): 1141-1154.

Worni R, Stoffel M, Huggel C, et al. 2012. Analysis and dynamic modeling of a moraine failure and glacier lake outburst flood at Ventisquero Negro, Patagonian Andes (Argentina). Journal of Hydrology, 444-445: 134-145.

Xiang Y, Gao Y, Yao T D. 2014. Glacier change in the Poiqu River basin inferred from Landsat data from 1975 to 2010. Quaternary International, 349: 392-401.

Xu D M. 1988. Characteristics of debris flow caused by outburst of glacial lake in Boqu River, Xizang, China, 1981. GeoJournal, 17(4): 569-580. 